\title{
Trade Service Agreement between Vietnam and the EAEU and The Formation of Negotiation Strategies on New Agreements in the Service Sector: The First Results ${ }^{1}$
}

\author{
V. Zuev, E. Ostrovskaya, E. Vasileva
}

\begin{abstract}
Vladimir Zuev - Doctor of Economics (PhD), Professor of the Institute of Trade Policy, National Research University Higher School of Economics (HSE University); bldg. 2, 17 Malaya Ordynka Ulitsa, Moscow, 115184, Russian Federation; E-mail:vzuev@hse.ru
\end{abstract}

Elena Ostrovskaya - Candidate of Economic Sciences, Associate Professor at the Faculty of World Economy and International Affairs, National Research University Higher School of Economics (HSE University); bldg. 2, 17 Malaya Ordynka Ulitsa, Moscow, 115184, Russian Federation; E-mail: eostrovskaya@hse.ru

Ekaterina Vasileva - Postgraduate student, National Research University Higher School of Economics (HSE University), Consultant of the Division of Systemic Conditions for Sectoral Cooperation, Department of Trade Policy of the Eurasian Economic Commission; bldg. 1, 3/5 Smolensky Boulevard, Moscow, 119002, Russian Federation; E-mail: 95VKate@gmail.com

\begin{abstract}
In the last decades, the importance of trade in services in global trade flows has grown from strength to strength. This trend has stimulated the proliferation of bilateral and multilateral trade agreements aimed at ensuring equal and fair access for service providers to foreign markets. The states of the Eurasian Economic Union are no exceptions to this global trend and strive to ensure free trade in services with foreign partners as a part of trade policies.

The article analyzes theoretical and practical aspects of implementing the provisions on trade in services of the Free Trade Agreement between the EAEU and Vietnam, specifically applied on Russia and Vietnam. The results of the Agreement implementation are instrumental in formulating the main contributions of the strategy that will increase the efficiency of future agreements on trade in services between the EAEU and foreign partners. The following strategy has already been applied on the example of service sector cooperation between Russia and Singapore. The emphasis of the study is quite universal, and the contributions of the strategy are applicable to other regional associations.
\end{abstract}

Key words: regional trade agreements; trade in services (service trade); schedules of specific commitments; free trade agreement between the EAEU and Vietnam; free trade agreement between the EAEU and Singapore

For citation: Zuev V., Ostrovskaya E., Vasileva E. (2021). The Trade Service Agreement Between Vietnam and the EAEU and The Formation of Negotiation Strategies on New Agreements in the Service Sector: The First Results. International Organisations Research Journal, vol. 16, no 2, pp. 183-203 (in English). DOI: 10.17323/1996-7845-2021-02-09

${ }^{1}$ The editorial board received the article in February 2021. 


\section{Introduction}

In six years, since the foundation, the Eurasian Economic Union and the Member States have concluded several trade agreements, including Vietnam, Iran, Serbia, and China, while continuing to develop in the field. Other agreements, specifically with Singapore (in terms of service trade and investments), Egypt, Israel, and India are still held at different stages of the negotiation process. The new trade agreements requires considering the experience of concluding and implementing previous agreements in order to increase the effectiveness of the ones in the future.

The purpose of the following stud ${ }^{2}$ is to identify the depth of the liberalization of trade in services between Russia and Vietnam. On the basis of the following agreement, it will be possible to analyze the results of its implementation, and to build a strategy pattern for the formation of specific commitments that may liberalize service trade and increase the effectiveness of future agreements afterward.

The steps to achieve the goal are listed below:

- analyzing key contributions on the regulation of trade in services under the multilateral trading system and regional trade agreements;

- analyzing of the agreements reached within the framework of the national contributions of specific commitments on trade in services between Russia and Vietnam;

- analyzing the results of the implementation of agreements between Russia and Vietnam on the basis of mutual trade flows data;

- evaluating the positive and negative effects of the commitments on trade in services between Russia and Vietnam;

- shaping the contribution of the negotiation strategy on the formation of commitments on trade in services under the Free Trade Agreement between the EAEU and the Republic of Singapore (using the example of Russia);

- offering the universal interpretation of the results of the implementation of the agreement.

The study of free trade agreements in terms of services sector has not yet found proper reflection in the scientific literature. However, in the last decade, this topic has acquired particular relevance, since the role of services in international trade is constantly growing. The agreement-based framework on regulating trade in services is constantly being expanded by new agreements. Yet, there has not been a proper theoretical and practical assessment of the quality of expanding these agreements with specific commitments that stimulate the trade in services.

This work is intended to partially fill this gap. Many scholars have studied certain aspects of the formation of free trade agreements and national schedules of specific commitments in terms of services between partnering countries [Roy, 2019; WTO, 2019; Gootiiz et al., 2020]. A number of articles by Russian researchers are devoted to assessing the effects of the concluded free trade agreement between the EAEU and Vietnam. However these works are mostly devoted to the analysis of the scope of the agreement [Vityuk, 2020; Ushkalova, 2018], as well as the impact of the agreement on trade in goods flows between the participating countries [Yakovlev, Glinkina, Turaeva, 2018; Tomilov, 2020]. We were unable to find a detailed analysis of the

${ }^{2}$ This research was prepared under the supervision of the Faculty of World Economy and International Affairs, of the National Research University Higher School of Economics. 
impact of specific commitments on trade in services and a critical assessment of the missing elements in the basic provisions of the Agreements in the mastered scientific literature.

\section{Preconditions for the Shaping of a System for Regulating Trade in Services under Regional Trade Agreements (RTAs)}

The rapidly growing number of regional trade agreements as a tool for regulating relations between partner countries has become an important feature of modern international trade. Such agreements are aimed not only at reducing customs duties, as it was in the beginning of the RTS development. It also includes expanded regime provisions on services and investments, as well as a number of non-regime chapters that contribute to trade liberalization (specifically, the chapters on technical barriers, sanitary and phytosanitary measures, intellectual property, competition).

The spread of RTAs on trade in services is connected with the establishment of the fundamental rules in the late $1990 \mathrm{~s}$, within the multilateral trading system of regulation, and along with the significant increase in the share of trade in services in the global volume of trade. Between 2000 and 2019, the share of trade in services in global GDP increased from $9.2 \%$ to $13.5 \%$ [World Bank, n. d., b]. The share of services in the structure of world trade in goods and services also increased - from $21 \%$ in 2000 to $25 \%$ in 2019 [Ibid.]. According to the latest data of 2015, the share of services in trade in the equivalent of value added (which is $49 \%)^{3}$ is not inferior to the commodity at all.

With the increase in global trade in services, the need for multilateral regulation of the sector has increased to create a transparent, non-discriminatory and predictable environment for services providers around the world. The General Agreement on Trade in Services (GATS) was signed during the Uruguay Round, and entered into force in 1995. The GATS has laid the fundamental basis for multilateral rules for trade in services, identified four possible modes of supply of services: cross-border supply, foreign consumption, commercial presence, private entity transfer. The GATS establishes such basic principles in service trade as most favored nation treatment, transparency, and the possibility of revising administrative decisions. The GATS also provides for the WTO member countries to take a number of commitments to provide national treatment and market access for foreign service providers. The multilateral agreement on trade in services has made it possible to fix the basic rules, protecting market participants from the instability of trade regimes. However, since the late 1990s, there have been no major decisions affecting trade in services within the WTO. At the same time, the need for new regulations has rised, which led to the transition of the liberalization of trade in services to the RTS format.

\section{First Results of the Implementation of the Free Trade Agreement between Russia and Vietnam in Terms of Trade in Services}

Being formed in 2014, the Eurasian Economic Union (EAEU) including the Republic of Belarus, the Republic of Kazakhstan, the Russian Federation, as well as the Republic of Armenia and the Kyrgyz Republic (the states that became full members of the Union in 2015) has chosen a strategy for concluding RTAs as one of the priorities of cooperation with the third countries. According to the Article 38 of the Treaty on the Eurasian Economic Union ("Foreign Trade in Services"), the Union does not have supranational competence in the field of trade in services

${ }^{3}$ Calculated by the author based on OECD data. Trade in Value Added Database [Electronic resource]. URL: https://stats.oecd.org/Index.aspx?DataSetCode=TIVA_2018_C1 
with third countries, therefore each Member State has the right to independently determine its trade policy in relation to trade in services, establishment, activity, and investment with third countries and conclude international agreements on economic integration in the field of trade in services and investments [Treaty on the Eurasian Economic Union, 2014, Appendix 16, Para. 6, Section VI].

Within the framework of the already signed free trade agreements, there is a section on trade in services only in the Agreement between the EAEU and Vietnam. However, this is a non-standard format, as the scope of Chapter 8 [VN-EAEU FTA, 2015] ("Trade in services, investment and movement of natural persons") is limited to the bilateral Russia-Vietnam pattern, while all other chapters of the agreement cover five EAEU Member States and Vietnam.

The first round of negotiations on trade in services, investment and the movement of natural persons was launched in March 2013, when the EAEU was not yet formed, and negotiations took place between the Customs Union of the Republic of Belarus, the Republic of Kazakhstan and the Russian Federation, on the one hand, and Vietnam, on the other hand. After several rounds of negotiations, the Republic of Kazakhstan and the Republic of Belarus changed the status of direct participants and parties to this section to observers. However, Article 8.9 ("Accession") reserves the right of other EAEU Member States to join this chapter later.

In order to identify what preferences Russia was able to fix for its national services providers, it is necessary to pay attention to the schedules of specific commitments of the parties. According to the international practice, at the moment of concluding free trade agreements in terms of trade in services, three formats for compiling schedules of specific commitments can be used [Group Author, 2017].

A positive format for the formation of schedules of specific commitments for trade in services involves fixing only those sectors in respect of which a party guarantees a certain level of access to its market for foreign services, service providers, investments and investors. Within the framework of the list, for each included sector, the commitments are formed separately for each of the four modes of supply. The use of this format is based on the provisions of the GATS.

The negative format of the schedules of specific commitments implies the fixation of only specific sectors, subsectors and restrictions (prohibitions) in relation to them, which one party can establish in relation to the access of foreign services, suppliers, investments and investors in their national market. In all sectors that are not listed, the party guarantees the ability to access its market without restrictions. Countries in the America, such as the North American Free Trade Area (NAFTA), began to use some of the first listing formats. The "Negative schedule" section also divided into two parts: one of which includes a list of "current" restrictions, and the other includes "future" restrictions. The list of "current" restrictions includes measures that are already applied in its territory and are restrictive for foreign services, services providers and investors. In the list of "future" restrictions, a party includes subsectors or measures in them, the right to apply to which it reserves in the future. The third format of schedules of specific commitments in trade in services is a mixed format that combines the two previous formats.

In the lists for Chapter 8, which regulates the terms of trade in services, investment and movement of individuals, the Russian Federation and Vietnam have chosen a combined format. Cross-border supply of services, consumption abroad, and movement of natural persons are regulated on the basis of "positive lists", while commercial presence is based on "negative lists". To analyze the degree of liberalization of market access recorded between the two Parties, a comparison was made of the commitments recorded by them in the lists to Chapter 8 of the Agreement and in the framework of the lists to the GATS.

In the course of the analysis of the liberalization of commitments made by the Parties under the chapter on trade in services, investment and movement of natural persons (see Appendix 1), it was found that neither Party has provided the other with any significant conces- 
sions on access to its services market. Thus, the results revealed do not allow us to announce a significant degree of liberalization of bilateral trade in services, in comparison with the already agreed upon by them in the framework of the WTO. Accordingly, the consequences of such liberalization turned out to be minimal.

However, for a more complete picture of the results of the implementation of the Agreement, in addition to the legal component, it is necessary to take into account the first practical results of the implementation of the Agreement in the framework of bilateral trade in services between Russia and Vietnam. In general, trade in services between the Russian Federation and Vietnam has been steadily increasing since 2012, with the exception of short-term minor declines in 2015 and 2018 (see Fig. 1). However, if we analyze the structure of this turnover, it is clear that the Russian Federation, both before and after the entry into force of the Agreement, is a net importer of services from Vietnam. In 2019, the import of services from Vietnam to Russia exceeded the export of Russian services to Vietnam by 4.4 times, which indicates a rather low competitiveness of Russian services in the Vietnamese market. ${ }^{4}$

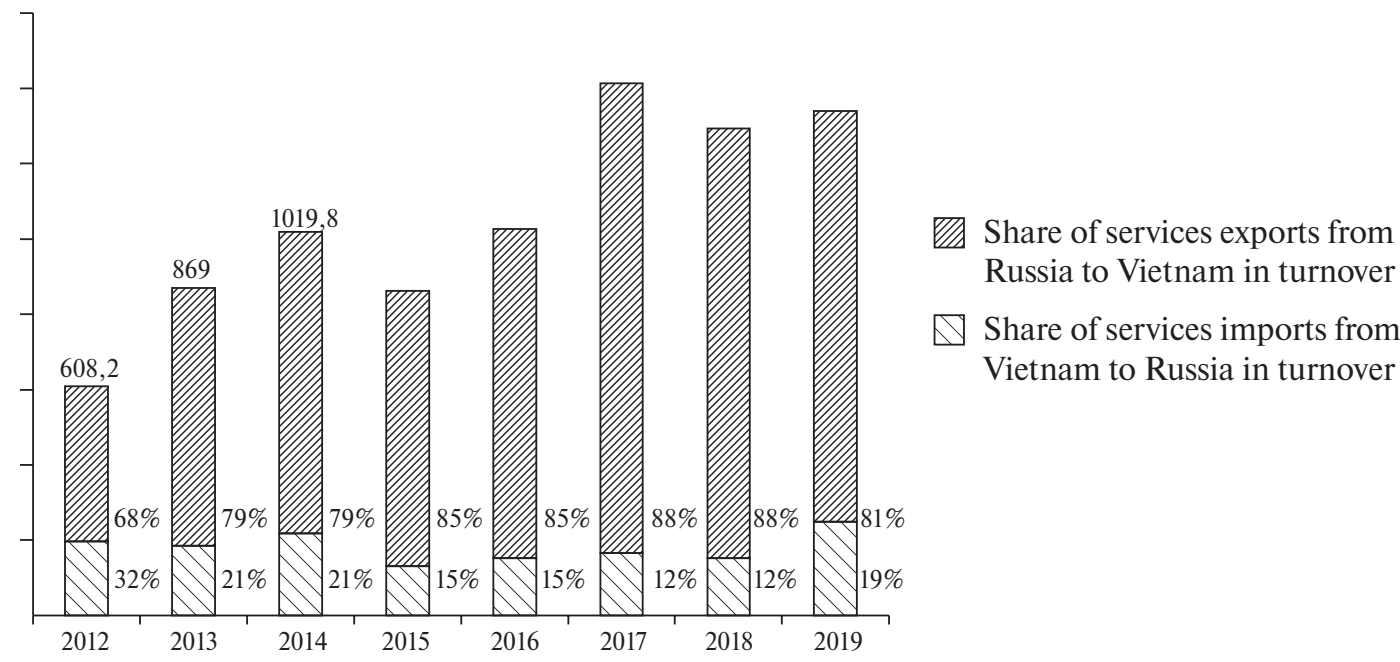

Fig. 1. Dynamics of trade turnover of services between Russia in Vietnam, million US dollars

Source: Compiled by the authors based on data from the Bank of Russia. Statistical collection "Foreign trade of the Russian Federation in services", 2020 [Electronic resource]. Available at: https:// www.cbr.ru/Collection/Collection/File/31434/External_Trade_in_Services_2019.pdf

Exports of Russian services to Vietnam from 2012 to 2019 varied from USD 197.6 million to the maximum value in 2019 - USD 248.1 million. After the signing of the Agreement in 2014, the export of Russian services to Vietnam collapsed by $40 \%$. The entry into force of the agreement in 2016 did not greatly affect the volume of exports of Russian services to the Vietnamese market - the volume fluctuated between 150-160 million US dollars, that is, at a level lower than before the conclusion of the Agreement. In 2019, the volume of exports reached its maximum value in 7 years, however, despite such a jump, the general trend in the export of Russian services to the Vietnamese market cannot be called positive (see Fig. 2).

${ }^{4}$ Authors' calculations based on data from the Bank of Russia. Statistical collection "Foreign trade of the Russian Federation in services", 2020. [Electronic resource]. Available at: https://www.cbr.ru/Collection/ Collection/File/31434/External_Trade_in_Services_2019.pdf 


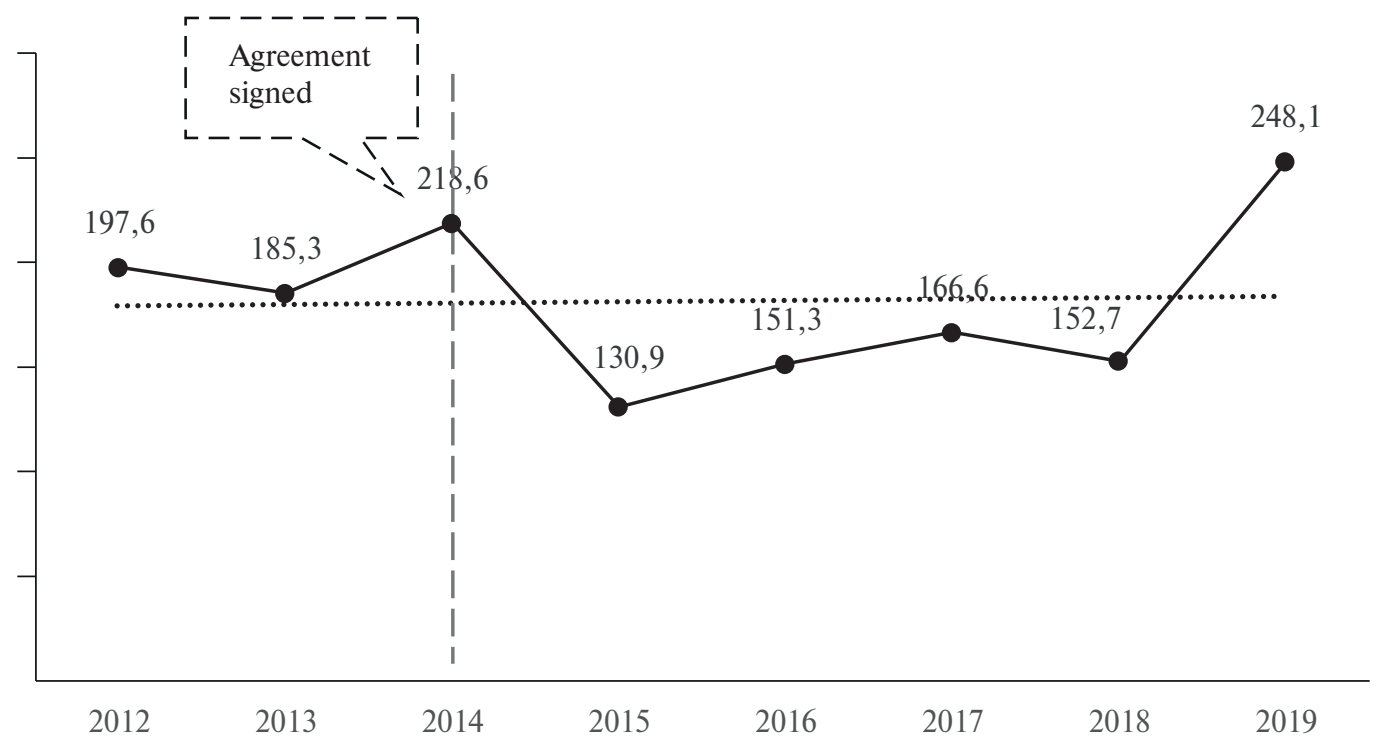

Fig. 2. Dynamics of export of services from Russia to Vietnam, million US dollars

Source: Compiled by the authors based on data from the Bank of Russia. Statistical collection "Foreign trade of the Russian Federation in services", 2020 [Electronic resource]. Available at: https:// www.cbr.ru/Collection/Collection/File/31434/External_Trade_in_Services_2019.pdf

There was also no diversification of the types of Russian services exported to Vietnam. In both 2014 and 2019, the largest share was accounted for by groups such as transportation, travel $^{5}$ and other business services (see Fig. 3). However, despite the wide range of exported services, their quantity and value are small, and the share of Russia in total imports of services by Vietnam is insignificant (less than $1 \%$ ).

In 2016-2019, there was a significant increase in Russian exports in the section of transport services (from \$ 23.4 million in 2016 to $\$ 84.2$ million in 2019), travel (from $\$ 54.9$ million in 2016 to $\$ 82.5$ million in 2019) and telecommunications, computer and information services (from $\$ 3.4$ million in 2016 to $\$ 5.3$ million in 2019) [Central Bank of the Russian Federation, 2020]. However, the Vietnamese side did not additionally open market access in these sectors under the Agreement.

Based on the foregoing, it can be concluded that the implementation of the Agreement did not directly have a significant impact on the volume and structure of trade in services between the Russian Federation and Vietnam. It can also be stated that the study of the schedules of specific commitments undertaken by the Parties in the framework of trade in services and analysis of statistical data on the dynamics and structure of bilateral trade in services showed that the agreements concluded between Russia and Vietnam regarding trade in services did not have a significant impact on the existing trade flows between the parties. They served only as an additional background to demonstrate the liberalization achieved in the commodity part.

${ }^{5}$ In accordance with the Methodology of the Central Bank of Russia, travel related to export of services includes temporary entries of non-resident individuals from a permanent place of residence to the territory of the Russian Federation and is defined as a set of expenses for the acquisition of goods and services in the Russian Federation for their own needs or for free transfer to other persons. 
If the goal of real liberalization is to be set, a significant expansion of commitments under future agreements with foreign partners in terms of services will be required, especially in the sectors of greatest interest to domestic suppliers. The use of "negative lists" for all four modes of supply can also help to gain trade effects, as this format includes a broader coverage of the sectors and sub-sectors of services to which the commitments are made.

\section{4}

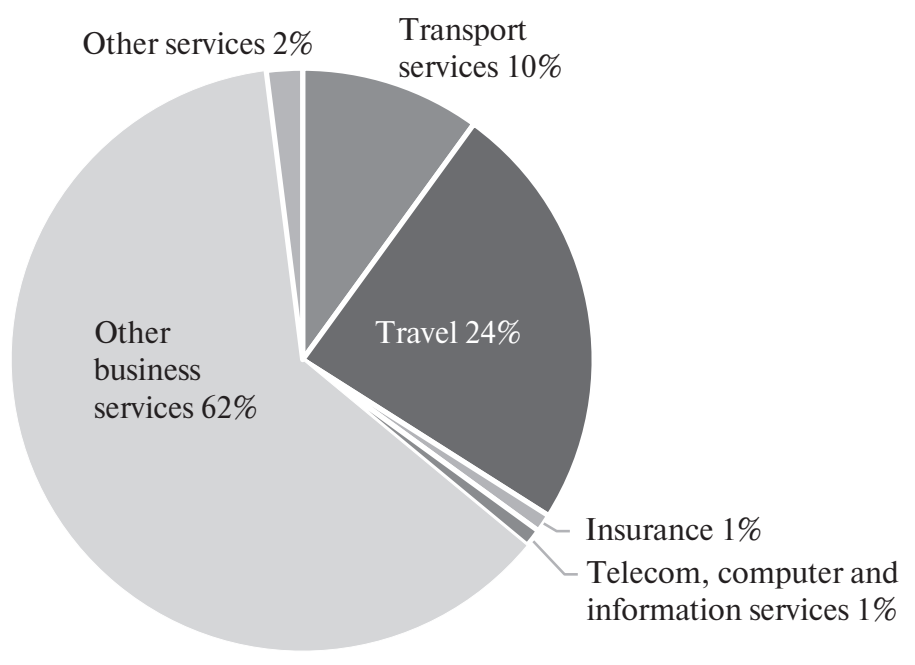

2019

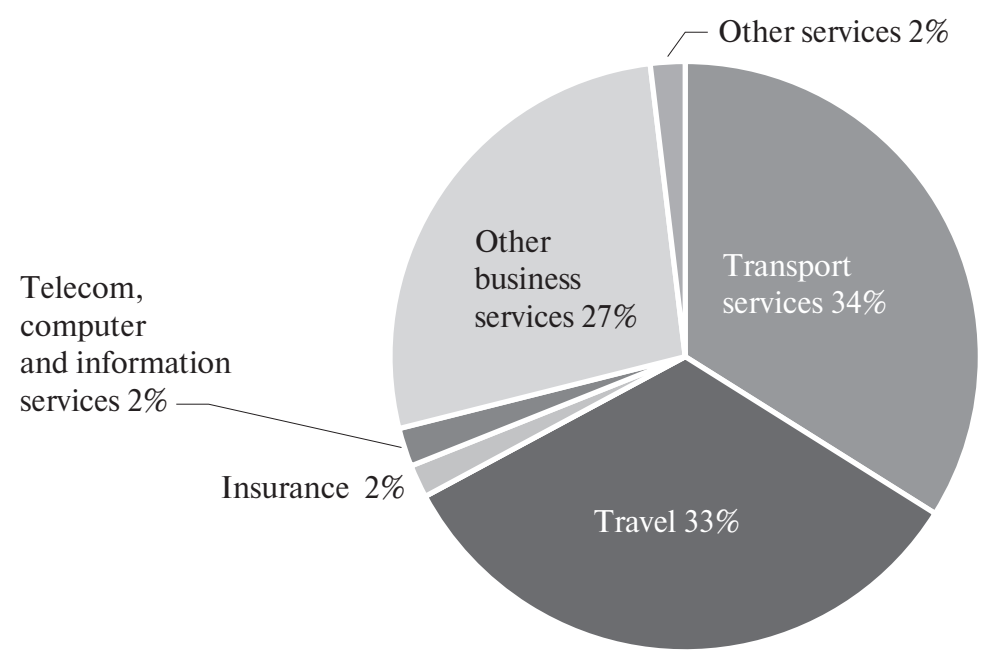

Fig. 3. Structure of export of services from Russia to Vietnam by sector in 2014 and 2019, \%

Source: Compiled by the authors based on data from the Bank of Russia. Statistical collection "Foreign trade of the Russian Federation in services", 2020 [Electronic resource]. URL: https://www. cbr.ru/Collection/Collection/File/31434/External_Trade_in_Services_2019.pdf 


\section{The Trade Format in Services between the EAEU, Russia and Singapore}

After the agreement on a free trade with Vietnam, the EAEU continued to develop negotiation tracks for the signing of similar agreements with other countries. Among such agreements was the Agreement on a free trade zone between the EAEU Member States and the Republic of Singapore. Negotiations on the conclusion of a free trade agreement between the EAEU Member States and Singapore began in 2017. On October 1, 2019, the parties signed the Framework Agreement on Comprehensive Economic Cooperation, as well as the Agreement on Free Trade in Goods. As regards bilateral agreements on trade in services and investments, at the moment, only the Republic of Armenia was able to fully complete the negotiations, the rest of the EAEU Member States continue to conduct them in terms of the formation of bilateral schedules of specific commitments. The main reason for such a delay in the negotiations is that the Singapore services market, while having significant attractiveness, is already bound by a number of commitments to liberalize access (in particular, within the framework of such agreements as the Association of Southeast Asian Nations for Services, the Comprehensive and Progressive Trans-Pacific Partnership, Free Trade Agreement between the European Union and Singapore, etc.), which leads to a high level of competition between domestic and foreign suppliers in the most important sectors. In this situation, Singapore is not interested in attracting additional suppliers of the EAEU Member States to its market on the same preferential terms that have already been provided to other large partners. For this reason, the Member States of the Union need to form a convincing and concrete position to protect their interests in the liberalization of access to the Singapore market in certain sectors in order to maximize the effectiveness of the concluded bilateral agreements.

Note that Singapore is a promising partner in trade in services. The services sector is key to the Singapore economy, with services accounting for about 70\% of the country's GDP (2019) [Statistics Singapore, n.d.]. In 2019, exports of services from Singapore accounted for 3.3\% of the global volume of exports of services (9th in the ranking of world exporters of services). Imports of services by Singapore accounted for 3.4\% of the total world imports (8th place in the ranking of world importers of services) [World Bank, n. d., a]. In addition, Singapore has extensive experience in participating in free trade agreements in terms of services -21 agreements [WTO, n. d., a], including such major agreements as: Framework Agreement of the Association of Southeast Asian Nations on Services (after ASEAN), Comprehensive and Progressive Trans- Pacific Partnership (hereinafter referred to as CPTPP), Free Trade Agreement between the European Union and Singapore (after referred to as the EU-Singapore FTA).

Taking into account the conclusions made earlier on the section on trade in services between Russia and Vietnam, it would be advisable for the EAEU Member States to follow the upcoming strategy in order to conclude a profitable agreement in the framework of trade in services:

1) Identify the sectors and subsectors of services in Singapore that may be of significant interest to national exporters of services of the EAEU states. To do this, one can take into account statistical data on those services sectors that are already leading in the structure of exports of the EAEU Member State to Singapore, since in such sectors, suppliers will have the opportunity to further increase trade volumes with the possible liberalization of access conditions. You can also pay attention to the services sectors, which are leading in the structure of Singapore's imports from other countries. With additional liberalization of such sectors, even if they are not currently key in the exports of a Member State of the EAEU to Singapore, the Member State of the EAEU will have the potential to achieve additional diversification. In addition, in identify- 
ing such sectors of significant interest, it is necessary to take into account the already existing infrastructure and the specifics of the functioning of each specific service market in Singapore;

2) Analyze the commitments for the identified sectors undertaken by Singapore in the list to the GATS and lists of specific commitments in free trade agreements with the largest partners;

3) Analyze the national legislation in the identified sectors for the presence in the list proposed by Singapore to the EAEU Member State, restrictions that are not directly recorded in national legislation. As noted above, international practice shows that the restrictions provided by national legislation are not eliminated within the framework of free trade zones.

As an example of the practical implementation of such a strategy, it can be examined in the context of bilateral relations between Russia and Singapore. In 2019, exports of services from the Russian Federation to Singapore amounted to $\$ 681.99$ million USA [Central Bank of the Russian Federation, 2020] (less than 1\% of Singapore's total imports of services "from the world"). The structure of Russian services exports to Singapore is dominated by such sectors as: transport services (56\%), business services (17.4\%), telecommunications, computer and information services (11\%), and construction services (7\%). ${ }^{6}$ To determine the level of market access to these sectors, we will compare the commitments recorded by Singapore in the GATS lists and in the largest FTA of Singapore - ASEAN [ASEAN, 2018], TPP [CPTPP, 2016] and EU- Singapore FTA [EUSFTA, 2019]. The difficulty of comparing commitments in this case is primarily due to the different format of the lists used in the above-mentioned FTA (see Annex 2).

The ASEAN Services Framework Agreement uses "positive lists" for the first three modes of supply (other than the movement of natural persons ${ }^{7}$ ). The lists of ASEAN member countries are being reviewed on an ongoing basis with a view to liberalizing access conditions for foreign services and service providers. At the moment, the 10th package of commitments on trade in services (entered into force in February 2019) and the 8th package of commitments on trade in financial services (entered into force in April 2019) are in force. Under the CPTPP (for Singapore, entered into force on December 30, 2018), Singapore uses the "negative format" of the lists. The EU-Singapore FTA (entered into force on 21 November 2019) uses «positive lists» that include all four modes of supply.

When analyzing the lists of these agreements, it becomes clear that within the framework of the concluded FTA on trade in services, Singapore significantly liberalizes access to its market for the key sectors listed above, compared to the level recorded in the GATS list. Particularly notable is the liberalization in the transport services sector, where only two subsectors of maritime transport services (freight transport and maritime support services) have been granted access under the WTO. At first glance, the most liberal conditions for access to the Singapore market are provided to them under the CPTPP. According to the current measures in the transport services sector, Singapore in the CPTPP fixes only a few restrictions on auxiliary services for maritime transport ${ }^{8}$, air transport services and pipeline transport. However, in the list of future measures (which Singapore has the right to apply at any time and with any degree of restrictions), Singapore reserves a fairly large number of possible measures (for example, in

\footnotetext{
${ }^{6}$ Compiled by the authors based on data from the Bank of Russia. Statistical collection "Foreign trade of the Russian Federation in services", 2020. [Electronic resource]. Available at: https://www.cbr.ru/Collection/ Collection/File/31434/External_Trade_in_Services_2019.pdf

${ }^{7}$ Issues related to the movement of natural persons within ASEAN are regulated by a separate Agreement ASEAN Agreement on Movement of Natural Persons.

${ }^{8}$ Only PSA Marine Pte Ltd or its successor is permitted to provide pilotage and desalinated water to vessels berthed in ports of Singapore or Singapore territorial waters Only PSA Corporation Ltd and Jurong Port Pte Ltd or their successors can provide cargo handling services. Only local service providers can provide cruise and ferry services.
} 
such sectors as: auxiliary services for maritime transport, air transport services, rail transport services, road transport services, additional services for all modes of transport). In the pipeline transport sector, the restrictions fixed in all Singapore FTA are equivalent in terms of the size of the restrictions, which indicates a high probability that these restrictions are based on national legislation and the specifics of the market organization in this sector, and therefore are not removed under the FTA. As for a large number of future restrictions, the possibility of their removal may be subject to more detailed study in the negotiation process in the event of a free trade agreement with Singapore, since, as noted earlier, such restrictions often do not have a clear legislative basis.

In the business services sector, the Singapore FTA is also significantly liberalizing market access. In addition to the fact that the "positive lists" in both ASEAN and the EU-Singapore FTA record access to a much larger number of sectors than in the WTO. Moreover, in sectors where significant restrictions were recorded in the WTO (Services in the field of architecture, Services in engineering areas), access is provided without restrictions under the FTA.

The telecommunications and banking sectors are usually the most closed in the GATS country lists. Within the framework of ASEAN, access to this sector is not liberalized in any way and is fixed at the same level as in the WTO. The CPTPP and the EU - Singapore FTA removed restrictions on the maximum amount of foreign investment in operators), which leads to the conclusion that this restriction may be subject to discussion in the framework of concluding future free trade agreements with Singapore.

The computer services and construction services sectors have the maximum degree of liberalization under both the WTO and the Singapore FTA. That is, any additional work to remove restrictions in these sectors when concluding future free trade agreements with Singapore is not required.

We will also pay detailed attention to the commitments, legislative regulation and structure of individual subsectors of interest to the Russian Federation from the point of view of exports and Singapore from the point of view of imports. The main export volume of the business services sector from the Russian Federation to Singapore falls on such categories as services in the field of architecture, engineering services (39\%); advertising, marketing, public opinion research (29\% of the total export of business services from the Russian Federation to Singapore); consulting services and public relations services $(7,65 \%)$ [Central Bank of the Russian Federation, 2020]. In the subsectors-advertising, marketing, public opinion research and consulting and public relations services, within the WTO and all the analyzed FTA of Singapore, access is already provided without restrictions.

With regard to architecture and engineering services, Singapore's GATS list provides for significant restrictions on commercial presence in these sectors. It should also be noted that in the national legislation of Singapore, restrictions are also fixed for these subsectors. Their removal from free trade agreements is most likely due to mutual recognition mechanisms, which is also subject to more detailed elaboration in the negotiation process when concluding a possible free trade agreement with Singapore.

In terms of transport services, the fundamentals of international regulation, as well as the specifics of Singapore's infrastructure, significantly narrow the areas of potential interest for Singapore in a possible free trade agreement in services. The sphere of inland water transport is extremely limited due to the small area of the state (the longest river in Singapore is the Kallang, its length is $10 \mathrm{~km}$ ). There is no rail transport in Singapore. International air traffic and road transport, in accordance with global practice, are the subject of separate bilateral agreements.

The main interest may be the conditions of access in the subsector of maritime transport services, as well as support services for both maritime transport and other modes of transport. The interest in these subsectors is also confirmed by statistical data. Maritime transport ac- 
counts for $75 \%$ of the total volume of transport services exported by the Russian Federation to Singapore, while $76.5 \%$ of the export of sea transport services is the export of auxiliary services for maritime transport. ${ }^{9}$

The analysis shows the possible directions of building a strategy for negotiations when concluding a free trade agreement on services, in this case - with Singapore. When setting the goal of improving the effectiveness of the agreement, the strategy should initially be based on a detailed study of the market access conditions offered by Singapore within its lists to the States of other associations (in our case, the Member States of the EAEU) in order to identify the sectors that are of greatest interest to service providers of each exporting state, and to identify among these sectors those in which it is most likely to achieve minimization of restrictions based on a comparative analysis of Singapore's commitments in other major agreements. This will become a kind of guide for choosing the sectors where liberalization will be most likely and most effective.

\section{Effects of Free Trade Agreements in Services, a New Negotiating Strategy}

As a result of the analysis, we come to a more complete understanding of the consequences of the introduction of a free trade regime for services. Access to the market for services and the application of the national regime for services are not unconditional, as in the case of goods. The reason lies in the differences in the nature of services compared to goods. When concluding agreements on free trade in goods, the key factor of effectiveness for each of the parties is the maximum reduction of import customs duties that are applied at the customs border of the importer in relation to the goods that the exporter supplies. After passing the customs clearance procedure, the goods enter the domestic market, where they should no longer face additional barriers.

The service does not have a material form, and therefore the crossing of any territorial borders by the service does not have a formal and procedural character, as in the case of goods. The terms of trade in services are determined only by the internal regulations of each country. The lists of restrictions on trade in services that countries draw up for free trade agreements, for the most part, are based precisely on the norms of national regulation. As practice shows, the probability that a country will make changes to its national legislation when concluding a free trade agreement with another country is extremely small.

Based on the protection of national services providers in the domestic market, as well as the security interests and social significance of certain subsectors of services (such as medical services, security agencies, etc.), the country reserves the right to additional restrictions from the application of the national regime for foreign service providers, which are not directly contained in its national legislation. However, such restrictions are highly likely to be fixed in agreements (on free trade) in the service sector with all partners of this country and their removal in a bilateral format will be problematic.

The schedule of specific commitments of a country to the GATS is the maximum level of restrictions that can be applied to it on access to its national market for foreign suppliers. In practice, given that many countries have fixed these lists to the GATS in the last century, and domestic regulation has changed significantly during this time, given the increasing dependence of the world economy on the services sector, a foreign service provider entering a new for-

\footnotetext{
${ }^{9}$ Compiled by the authors based on data from the Bank of Russia. Statistical collection "Foreign trade of the Russian Federation in services", 2020 [Electronic resource]. Available at: https://www.cbr.ru/Collection/ Collection/File/31434/External_Trade_in_Services_2019.pdf
} 
eign market is primarily guided by the norms of national legislation applied within this market, such as registration requirements, the maximum allowed amount of foreign capital, etc., as well as additional bilateral agreements between the parties on mutual recognition of qualifications and suppliers. The restrictions set out in the GATS and free trade agreements mainly serve as marginal benchmarks that ensure that foreign service providers' access does not deteriorate below a certain level.

Bearing that in mind, it could be argued that free trade agreements in the sphere of trade in services, in the form in which they are currently agreed upon (as in the observed case of the Agreement between Russia and Vietnam), will not introduce significant quantitative changes in flows of services, on the contrary to their possible occurrence in the trade of goods. It should also be taken into account that the restrictions imposed by the national legislation within the framework of free trade zones are not usually eliminated, which has been shown by the experience of the Agreements with Vietnam and Singapore.

If we accept this statement, it is highly probable to get the impression that there is no point in signing services agreements at all. However, we still hold to the opinion that such agreements are expedient even now, and they will be even more relevant and needed in the future due to the constantly increasing role of services in international trade.

In any case, the parties entering into negotiations on free trade in services have the opportunity to seek the maximum possible removal of restrictions that are not contained in the national legislation of the other party, but are additionally recorded by this party in order to protect national services providers. For the purpose of accomplishing the given task, while signing the agreement on the establishment of the free zone in the sphere of trade in services, it is necessary to conduct a detailed comparative analysis of the schedules of specific commitments of a partner within the framework of GATS, agreement on the establishment of the free zone in the sphere of trade in services with other states as well as national regulations, especially the sectors of potential interest for the national suppliers.

The results of the study allow us to draw up an approximate universal roadmap for signing more effective, in comparison with the existing ones, agreement on trade in services, which implies:

1. Identification of sectors and sub-sectors of services that may be of significant interest for national exporters of services.

2. Analysis of the commitments for the identified sectors, accepted by the state involved in the negotiations process, in our case, Vietnam or Singapore, in the schedule to the GATS and in the schedules of specific commitments in the free trade agreements with the major partners.

3. Analysis of national legislation in the identified sectors for the presence in the schedule proposed by the country with which negotiations are held, restrictions that are not precisely stated in national legislation.

Despite the fact that the study revealed insignificant consequences of the conclusion of Free trade agreements in the sphere of trade in services for Russia in the researched period, it should be taken into account that Russia and its partners are not the leaders in the provision of services in the world, therefore the consequences of the conclusion of an FTA in the sphere of trade in services should be tested further following the example of associations and countries occupying a more significant niche in this area. Furthermore, as the study indicated, the parties have so far taken a very cautious position on lifting restrictions, compared with the existing levels of liberalisation in the WTO, which also was the reason for the poor performance of the Agreement. As the role of the services sector in trade will continue to grow, consequently, the importance of agreements in the sphere of services will also grow, which will determine the research interest in the problem in the upcoming years. 


\section{References}

Association of Southeast Asian Nations (ASEAN) (2018). Framework Agreement on Services: Annexes to the Protocol to Implement the Tenth Package of Commitments Under the ASEAN Framework Agreement on Services. Available at: https://asean.org/?static_post=member-countries-horizontal-commitments-schedulesofspecific-commitments-and-the-list-of-most-favoured-nation-exemptions (accessed 16 May 2021).

Central Bank of Russian Federation (2020). Vneshnyaya torgovlya Rossijskoj Federacii uslugami [External Trade in Services of the Russian Federation]. Available at: https:/www.cbr.ru/Collection/Collection/ File/31434/External_Trade_in_Services_2019.pdf (accessed 25 February 2021) (in Russian).

Comprehensive and Progressive Agreement for Trans-Pacific Partnership (CPTPP) (2016). Annex I - CrossBorder Trade in Services and Investment Non-Conforming Measures and Annex II - Cross-Border Trade in Services and Investment Non-Conforming Measures. Available at: https://www.mfat.govt.nz/en/trade/ freetrade-agreements/free-trade-agreements-in-force/comprehensive-and-progressive-agreement-for-transpacific-partnership-cptpp/comprehensive-and-progressive-agreement-for-trans-pacific-partnership-textandresources/\#bookmark2 (accessed 16 May 2021).

Free Trade Agreement Between the Eurasian Economic Union and its Member States, of the One Part, and the Socialist Republic of Viet Nam, of the Other Part (VN-EAEU FTA) (2015). Available at: http://www.eurasiancommission.org/ru/act/trade/dotp/sogl_torg/Documents/EAEU-VN_FTA.pdf (accessed 16 May 2021).

Free Trade Agreement Between the European Union and the Republic of Singapore (EUSFTA) (2019). Annex 8-B: Singapore's Schedule of Specific Commitments. Available at: https://eur-lex.europa.eu/legal-content/ $\mathrm{EN} / \mathrm{TXT} / \mathrm{PDF} /$ ?uri=CELEX:22019A1114(01)\&from $=\mathrm{EN} \#$ page $=1$ (accessed 16 May 2021).

Gootiiz B., Jonetzko G., Magdeleine J., Marchetti J., Mattoo A. (2020). Services. Handbook of Deep Trade Agreements (A. Mattoo, N. Rocha, M. Ruta (eds)). Washington DC: World Bank Group. Available at: https:// openknowledge.worldbank.org/handle/10986/34055 (accessed 16 May 2021).

Organisation for Economic Co-operation and Development (OECD) (n. d.). Trade in Value Added (TiVA): Principal Indicators. Available at: https://stats.oecd.org/Index.aspx?DataSetCode=TIVA_2018_C1 (accessed 20 February 2021).

Pravila VTO i osnovy torgovoj politiki (2017). [WTO Rules and Fundamentals of Trade Policy]. Moscow: International Relations (in Russian).

Roy M. (2019). Elevating Services: Services Trade Policy, WTO Commitments, and Their Role in Economic Development and Trade Integration. WTO Staff Working Paper, no ERSD-2019-01, World Trade Organization. Available at: https://www.wto.org/english/res_e/reser_e/ersd201901_e.pdf (accessed 16 May 2021).

Statistics Singapore (n. d.). Available at: https://www.singstat.gov.sg/modules/infographics/economy (accessed 20 February 2021).

Tomilov M.V. (2020). Perspektivy uglubleniya torgovoj integracii mezhdu uchastnikami EAES i stranami ATR [Prospects for Deepening Trade Integration Between the EAEU Members and the APR Countries]. Vlast' $i$ upravlenie na Vostoke Rossii [Power and Management in the East of Russia], no 3 (92) (in Russian).

Treaty on the Eurasian Economic Union (2014). Prilozhenie N 16 ("Protokol o torgovle uslugami, uchrezhdenii, deyatel'nosti i osushchestvlenii investicij”) [Appendix no 16 (Protocol on Trade in Services, Establishment, Activities and Investment)]. Available at: http://www.consultant.ru/document/cons_doc_LAW_163855/13ae 647de97b91e27fc376a7601927bbf5b2491a/ (in Russian).

Ushkalova D.I. (2018). Soglashenie o zone svobodnoj torgovli mezhdu EAES i V'etnamom: mekhanizmy torgovoj integracii [Agreement on a Free Trade Zone Between the EAEU and Vietnam: Mechanisms of Trade Integration]. Vestnik Instituta ekonomiki RAN [Bulletin of the Institute of Economics of the Russian Academy of Sciences], no 6 (in Russian).

Vityuk V.V. (2020). Tarifno-preferencial'nyj rezhim svobodnoj torgovli mezhdu EAES i Socialisticheskoj Respublikoj V'etnam i ego soderzhanie Tamozhennaya politika Rossii na Dal'nem Vostoke [Preferential Tariff Free Trade Regime Between the EAEU and the Socialist Republic of Vietnam and Its Content]. Tamozhennaya politika Rossii na Dal'nem Vostoke [Russia's Customs Policy in the Far East], no 1(90). 
World Bank (n. d., a). DataBank. Service Exports. Available at: https://data.worldbank.org/indicator/BX.GSR. NFSV.CD?year_high_desc $=$ true (accessed 20 February 2021).

World Bank (n. d., b). Data Bank: Trade. Available at: https://data.worldbank.org/indicator (accessed 20 February 2021).

World Trade Organization (2019). World Trade Report 2019: The Future of Services Trade. Available at: https://www.wto.org/english/res_e/booksp_e/00_wtr19_e.pdf (accessed 20 February 2021).

World Trade Organization (n. d.). Regional Trade Agreements Database. Available at: http://rtais.wto.org/UI/ publicsummarytable.aspx (accessed 20 February 2021).

Yakovlev A.A., Glinkina S.P., Turaeva M.O. (2017). Razvitie Zony svobodnoj torgovli EAES - V'etnam i factor Kitaya [Development of the EAEU-Vietnam Free Trade Zone and the China Factor]. Innovacii i investicii [Innovations and Investments], no 6 (in Russian). 


\section{Appendix 1. Levels of Liberalisation of the Services Market in the Schedules of Specific Commitments of Russia and Vietnam}

\begin{tabular}{|c|c|c|}
\hline & Russian Federation & Vietnam \\
\hline $\begin{array}{l}1 \text { delivery } \\
\text { method } \\
\text { (cross-border } \\
\text { delivery) }\end{array}$ & Obligations of GATS + are not accepted & $\begin{array}{l}\text { Obligations without limitations ac- } \\
\text { cepted in new services sub-sectors: } \\
\text { - Conveying research work, creat- } \\
\text { ing prototypes in the field of } \\
\text { natural sciences and interdisci- } \\
\text { plinary fields; } \\
\text { - Boat rental services without } \\
\text { operators; } \\
\text { - Cleaning services }\end{array}$ \\
\hline $\begin{array}{l}2 \text { delivery } \\
\text { method } \\
\text { (consumption } \\
\text { abroad) }\end{array}$ & Obligations of GATS + are not accepted & $\begin{array}{l}\text { Obligations without limitations ac- } \\
\text { cepted in new services sub-sectors: } \\
\text { - Conveying research work, creat- } \\
\text { ing prototypes in the field of } \\
\text { natural sciences and interdisci- } \\
\text { plinary fields; } \\
\text { - Boat rental services without } \\
\text { operators; } \\
\text { - Cleaning services }\end{array}$ \\
\hline $\begin{array}{l}3 \text { delivery } \\
\text { method } \\
\text { (commercial } \\
\text { presence) }\end{array}$ & $\begin{array}{l}\text { Obligations without limitations accepted in new ser- } \\
\text { vices sub-sectors: } \\
\text { - Services in the R\&D field (conveying research work, } \\
\text { creating prototypes in the field of natural sciences } \\
\text { and interdisciplinary fields); } \\
\text { - Recreational services (services of libraries, archives, } \\
\text { museums and other culture-educational institutions, } \\
\text { and organisation of sporting activities and other } \\
\text { types of leisure); } \\
\text { - With regard to a number of other new sub-sectors of } \\
\text { services, for which there were no obligations in the } \\
\text { WTO (railway, inland waterways, pipelines, space } \\
\text { transport), Russia de jure accepted obligations, } \\
\text { providing for such restrictions that de facto restrict } \\
\text { access to its market. } \\
\text { - More liberal conditions for access to the Russian } \\
\text { market were provided for a number of sub-sectors, } \\
\text { which were already recorded in the schedules of spe- } \\
\text { cific commitments of Russia in the GATS, namely, } \\
\text { services: accounting in the field of architecture; in } \\
\text { the field of urban planning and landscape architec- } \\
\text { ture; other business services and services of hotels and } \\
\text { places of temporary residence. } \\
\text { - The right to introduce measures in a number of sub- } \\
\text { sectors has been enshrined: maintenance and repair } \\
\text { of railway equipment, ancillary services for all types } \\
\text { of transport, radio communication services, postal } \\
\text { services, cinema and video projection services, tech- } \\
\text { nical testing and analysis, subsoil use services, con- } \\
\text { struction of infrastructure facilities, transportation oil } \\
\text { and gas }\end{array}$ & $\begin{array}{l}\text { Obligations of GATS+ are not ac- } \\
\text { cepted. } \\
\text { For all those sectors for which Vi- } \\
\text { etnam did not take commitments } \\
\text { under the WTO, a clause on "fu- } \\
\text { ture" measures was recorded in } \\
\text { the "negative list" for commercial } \\
\text { presence: "Vietnam reserves the right } \\
\text { to establish or maintain any measure } \\
\text { inconsistent with the obligations of } \\
\text { national regime, most favored na- } \\
\text { tion treatment, market access ... for } \\
\text { the sectors and subsectors mentioned } \\
\text { above" } 10\end{array}$ \\
\hline
\end{tabular}

${ }^{10}$ Annex 3 to Protocol № 1 between the Socialist Republic of Viet Nam and the Russian Federation to the Free Trade Agreement between the Socialist Republic of Viet Nam, on the one part, and the Eurasian Economic Union and its Member States, of the other part. List of reservations of the Socialist Republic Viet 


\begin{tabular}{|c|c|c|}
\hline & Russian Federation & Vietnam \\
\hline $\begin{array}{l}4 \text { delivery } \\
\text { method } \\
\text { (movement of } \\
\text { individuals) }\end{array}$ & Obligations of GATS + are not accepted & $\begin{array}{l}\text { Obligations without limitations ac- } \\
\text { cepted in new services sub-sectors: } \\
\text { - Conveying research work, creat- } \\
\text { ing prototypes in the field of } \\
\text { natural sciences and interdisci- } \\
\text { plinary fields; } \\
\text { - Boat rental services without } \\
\text { operators; } \\
\text { - Cleaning services; } \\
\text { - Packaging services }\end{array}$ \\
\hline
\end{tabular}

Source: Complied by the authors based on Annex 2 and Annex 3 to Protocol №1 between the Socialist Republic of Viet Nam and the Russian Federation to the Free Trade Agreement between the Socialist Republic of Viet Nam, on the one part, and the Eurasian Economic Union and its Member States, of the other part. URL: http://rtais.wto.org/rtadocs/973/AnnexAndRelatedDocs/English/ VCUFTA\%20Protocol\%20No.\%201\%20Full-1.pdf

Nam under section III (Establishment, Commercial Presence and Activities) of Chapter 8 (Trade in services, investment and movement of natural persons) of the agreement - Reservation № 64. 


\section{Appendix 2. Comparison of the Main Obligations of Singapore by Services in Sectors, Prevailing in the Structure of Russian Services Exports}

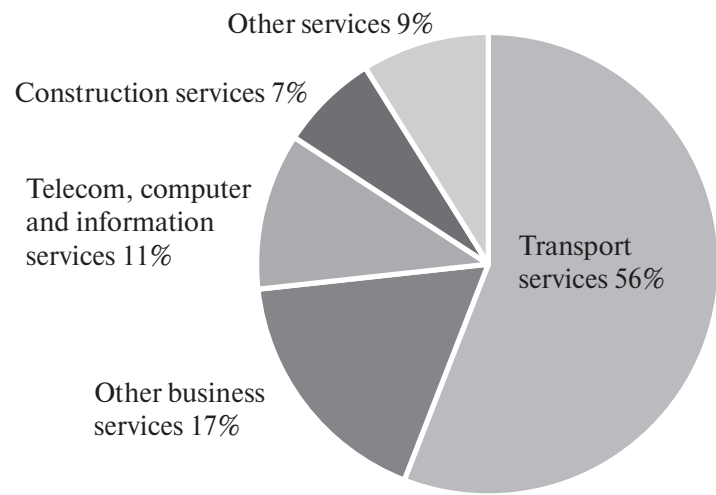

\begin{tabular}{|c|c|c|c|c|}
\hline Sector & $\begin{array}{c}\text { Singapore's } \\
\text { obligations within } \\
\text { the WTO }\end{array}$ & $\begin{array}{l}\text { Obligations within the } \\
\text { ASEAN }\end{array}$ & Obligations within the TPP & $\begin{array}{c}\text { Obligations within the FTZ EU- } \\
\text { Singapore }\end{array}$ \\
\hline 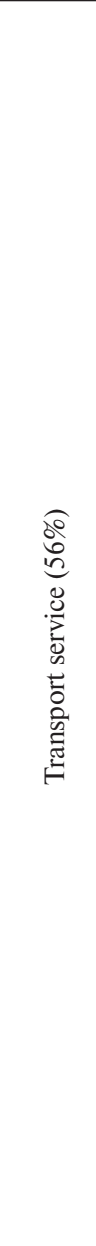 & $\begin{array}{l}\text { Access is not } \\
\text { guaranteed, with } \\
\text { the exception for } \\
\text { freight trans- } \\
\text { portation and } \\
\text { ancillary maritime } \\
\text { transport services } \\
\text { (maritime agency } \\
\text { services, customs } \\
\text { brokerage ser- } \\
\text { vices) without } \\
\text { restrictions }\end{array}$ & $\begin{array}{l}\text { For maritime transport } \\
\text { services: access is guar- } \\
\text { anteed in all subsectors } \\
\text { with restrictions on the } \\
3^{\text {rd }} \text { delivery method (for } \\
\text { the maximum amount } \\
\text { of foreign capital and the } \\
\text { registration of ships under } \\
\text { the Singapore flag). } \\
\text { For services of non- } \\
\text { maritime water transport: } \\
\text { access is guaranteed in all } \\
\text { subsectors with restric- } \\
\text { tions on the } 3^{\text {rd }} \text { delivery } \\
\text { method (for the maxi- } \\
\text { mum amount of foreign } \\
\text { capital). } \\
\text { Air transport services: ac- } \\
\text { cess is not guaranteed. } \\
\text { Railway transport services: } \\
\text { almost no access provided } \\
\text { (no obligations have been } \\
\text { accepted on methods } 1 \\
\text { and 3). } \\
\text { Road transport services: } \\
\text { access guaranteed (except } \\
\text { for passenger traffic). } \\
\text { Pipeline transport: access } \\
\text { is not guaranteed (no } \\
\text { obligations accepted for } 1 \text { st } \\
\text { and } 3^{\text {rd }} \text { delivery methods). } \\
\text { Ancillary and ancillary } \\
\text { services for transport: ac- } \\
\text { cess is guaranteed in some } \\
\text { sub-sectors of warehouse } \\
\text { and pack-house services }\end{array}$ & $\begin{array}{l}\text { For maritime transport ser- } \\
\text { vices: access is guaranteed } \\
\text { in all subsectors, except } \\
\text { for ancillary services for } \\
\text { maritime transport. In the } \\
\text { subsectors, shunting ser- } \\
\text { vices and ancillary services } \\
\text { for maritime transport } \\
\text { have the right to introduce } \\
\text { new restrictions. } \\
\text { For services of non-mari- } \\
\text { time water transport: access } \\
\text { with no limits. } \\
\text { Air transport services: cur- } \\
\text { rent restrictions remain, } \\
\text { new restrictions are } \\
\text { possible. } \\
\text { Rail transport services: } \\
\text { access with no limits. New } \\
\text { restrictions in all subsec- } \\
\text { tors are possible. } \\
\text { Road transport services: } \\
\text { access with no limits. New } \\
\text { restrictions in all subsec- } \\
\text { tors are possible almost in } \\
\text { all sectors. } \\
\text { Pipeline transport: access } \\
\text { with significant restric- } \\
\text { tions (for gas - the } \\
\text { presence of a license, } \\
\text { which, taking into account } \\
\text { the size of the market, is } \\
\text { issued to only one single } \\
\text { company; for oil and oil } \\
\text { products - local presence) } \\
\text { Ancillary and additional } \\
\text { services for all types of } \\
\text { transport: under the cur- } \\
\text { rent regulations - access is } \\
\text { unlimited. New restric- } \\
\text { tions are possible } \\
\text { ald }\end{array}$ & $\begin{array}{l}\text { For maritime transport services: } \\
\text { access is guaranteed for passenger } \\
\text { and cargo transportation with } \\
\text { restrictions on the } 3 \text { rd delivery } \\
\text { method (for the registration of } \\
\text { ships under the Singapore flag). } \\
\text { There are several restrictions on } \\
\text { ancillary services. } \\
\text { For services of non-maritime water } \\
\text { transport: access is not guaranteed. } \\
\text { Air transport services: access is not } \\
\text { guaranteed. } \\
\text { Rail transport services: access is } \\
\text { guaranteed only in the sub-sector } \\
\text { of maintenance and repair of } \\
\text { railway equipment. } \\
\text { Road transport services: access } \\
\text { is guaranteed in the following } \\
\text { sub-sectors: rental of commercial } \\
\text { vehicles with a driver (no obliga- } \\
\text { tion for the } 1^{\text {st }} \text { method of delivery } \\
\text { accepted), Transportation of } \\
\text { certain types of goods (for the } 1^{\text {st }} \\
\text { method of delivery no obligations } \\
\text { are accepted), maintenance and } \\
\text { repair of road transport equip- } \\
\text { ment (no restrictions) and parking } \\
\text { services (with no restrictions). } \\
\text { Pipeline transport: no obligations } \\
\text { accepted for } 1^{\text {st }} \text { and } 3^{\text {rd }} \text { delivery } \\
\text { methods. } \\
\text { Ancillary and additional services } \\
\text { for all types of transport: access is } \\
\text { guaranteed only to the sub-sector } \\
\text { of storage and warehousing ser- } \\
\text { vices, including warehouse and } \\
\text { pack-house services (no obliga- } \\
\text { tions are accepted for } 1^{\text {st }} \text { and } 3^{\text {rd }} \\
\text { delivery methods; for } 2^{\text {nd }}- \\
\text { no restrictions) } \\
\text { and }\end{array}$ \\
\hline
\end{tabular}




\begin{tabular}{|c|c|c|c|c|}
\hline Sector & $\begin{array}{l}\text { Singapore's } \\
\text { obligations within } \\
\text { the WTO }\end{array}$ & $\begin{array}{c}\text { Obligations within the } \\
\text { ASEAN }\end{array}$ & Obligations within the TPP & $\begin{array}{c}\text { Obligations within the FTZ EU- } \\
\text { Singapore }\end{array}$ \\
\hline 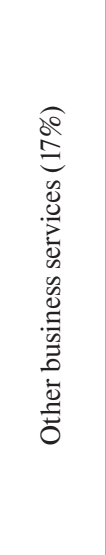 & \begin{tabular}{|l|} 
Access is guaran- \\
teed in about $45 \%$ \\
sub-sectors of \\
business services* \\
The largest num- \\
ber of restrictions \\
are recorded in \\
such subsectors \\
as: Services in the \\
field of architec- \\
ture, Services in \\
engineering fields, \\
Services in the \\
field of report- \\
ing, audit and \\
accounting, and \\
Services in the \\
field of taxation
\end{tabular} & $\begin{array}{l}\text { Access is guaranteed in } \\
\text { almost all sub-sectors of } \\
\text { business services. Access } \\
\text { is guaranteed in the major } \\
\text { part of sub-sectors with } \\
\text { no restrictions. } \\
\text { Some restrictions are pre- } \\
\text { sent in } 7 \text { sub-sectors only }\end{array}$ & $\begin{array}{l}\text { In the list of "existing } \\
\text { measures" restrictions are } \\
\text { present in the services sec- } \\
\text { tor: rental of vehicles and } \\
\text { other ground transport } \\
\text { equipment without an } \\
\text { operator; investigation and } \\
\text { security provision. There } \\
\text { are no restrictions in all } \\
\text { other sectors. New restric- } \\
\text { tions in the sub-sectors of } \\
\text { services are possible: legal, } \\
\text { real estate, consulting in } \\
\text { scientific and technical } \\
\text { fields, publishing and } \\
\text { printing }\end{array}$ & $\begin{array}{l}\text { Access is guaranteed in almost all } \\
\text { sectors of business services. The } \\
\text { access level is generally equivalent } \\
\text { to that provided by ASEAN. }\end{array}$ \\
\hline 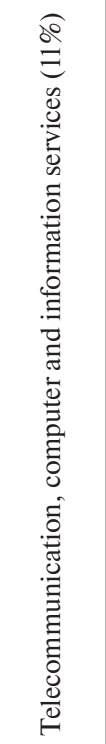 & \begin{tabular}{|l|} 
Computer services: \\
access with no \\
restrictions. \\
Telecommunication \\
services: access \\
with restric- \\
tions on foreign \\
investment. The \\
maximum share of \\
foreign invest- \\
ments in operators \\
is $73.99 \%$ ( $49 \%$ of \\
direct investments \\
and $24.99 \%$ of \\
portfolio invest- \\
ments). Cross- \\
border delivery is \\
possible if agree- \\
ments are signed \\
with licensed \\
operators. Com- \\
mercial presence \\
is limited
\end{tabular} & $\begin{array}{l}\text { Computer services: access } \\
\text { with no restrictions. Tel- } \\
\text { ecommunication services: } \\
\text { access guaranteed on } \\
\text { terms equivalent to the } \\
\text { WTO }\end{array}$ & \begin{tabular}{|l|} 
Computer services: access \\
with no restrictions. Tel- \\
ecommunication services: \\
access guaranteed with \\
restrictions: \\
- operators and provid- \\
ers must be registered \\
in Singapore under the \\
Companies Act; \\
- the number of issued \\
licenses is limited due to \\
the scarcity of resources. \\
In the list of "future \\
measures" has the right \\
to impose restrictions in \\
certain sectors
\end{tabular} & $\begin{array}{l}\text { Computer services: access with } \\
\text { no restrictions. Telecommunica- } \\
\text { tion services: access on the terms } \\
\text { of the possibility of cross-border } \\
\text { supply only subject to signing } \\
\text { of commercial agreements with } \\
\text { licensed operators and limited } \\
\text { licenses for commercial presence. } \\
\text { There is also the commercial pres- } \\
\text { ence requirement that all service } \\
\text { providers must be incorporated as } \\
\text { companies under the Companies } \\
\text { Act (Cap. 50) }\end{array}$ \\
\hline 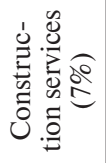 & $\begin{array}{l}\text { Access is guar- } \\
\text { anteed with no } \\
\text { restrictions }\end{array}$ & $\begin{array}{l}\text { Access is guaranteed with } \\
\text { no restrictions }\end{array}$ & $\begin{array}{l}\text { Access is guaranteed with } \\
\text { no restrictions }\end{array}$ & $\begin{array}{l}\text { Access is guaranteed with no } \\
\text { restrictions }\end{array}$ \\
\hline
\end{tabular}

* The comparison of regulation of this sector was carried out according to the subsectors of Business Services, identified in the GATS services sectoral classification list.

Source: Compiled by the authors based on the schedules to the relevant Agreements.

${ }^{11}$ The right is reserved to take any measure that confers treatment on the other party, equivalent to any measure taken or supported by that other party, limiting the ownership of persons of Singapore companies involved in the provision of public mobile and wireless communications in that other party's territory. The right is also reserved to take any measures that provide differential treatment for countries under any international agreement entered into force or signed after the date of entry into force of the Agreement, which includes telecommunications issues. 